\title{
Antonio Gomes Penna
}

\begin{abstract}
$A$ ntonio Gomes Penna nasceu em 13 de maio de 1917, no Rio de Janeiro. Sua contribuição pioneira à Psicologia brasileira é atestada por vários historiadores. Parte desta contribuição está expressa nos 14 livros que publicou. O Prof. Penna realizou duas docências-livres, em Psicologia e em Psicologia Educacional. Exerceu várias funções acadêmicas, entre elas, a chefia do Centro de Pós-graduação em Psicologia do ISOP, da Fundação Getúlio Vargas. Atualmente é professor emérito da Universidade Federal do Rio de Janeiro. Antonio Gomes Penna concedeu esta entrevista a Elza Dutra, psicóloga e professora da UFRN, no Rio de Janeiro, em outubro de 1996.
\end{abstract}

(EP): Inicialmente eu gostaria que o senhor falasse um pouco sobre a sua formação.

Antonio Gomes Penna (AGP): A minha formação foi um pouco complicada. $\mathrm{Eu}$ sou filho de imigrante; meu pai era industrial, queria que eu me dedicasse a vida econômica e o sucedesse na fábrica. Eu não tinha interesse mas, para atender a ele, fiz o curso de Economia que, naquela época, estava se iniciando. Mas depois me entusiasmei por Direito. A faculdade de Direito tinha professores muito badalados, grandes nomes. Depois fui fazer Filosofia, que eu desejava muito, onde se podia estudar Psicologia. O meu encanto era Filosofia e Psicologia. Lá eu encontrei grandes professores; foi lá que eu me realizei mesmo. Quando eu terminei, fui convidado para ser professor de História da Filosofia e professor da Psicologia. Eu preferi a Psicologia. A minha formação então foi essa, Economia, Direito e Filosofia. Depois dos três cursos de graduação, me dediquei inteiramente à Psicologia. Naquela época não havia psicólogos, apenas profissionais que se 
especializavam em Psicologia. Ou eram psiquiatras, estudavam psicopatologia, liam alguma coisa sobre anormal, ou então os que faziam curso de Pedagogia, estudavam um pouco de Psicologia Educacional e uma introdução de Psicologia Geral. Mas já havia o curso de Psicologia no departamento de Filosofia, com três anos de duração; aí sim, era um curso mais rico, da Universidade do Brasil.

(EP): O Prof. Nilton Campos era o responsável por este curso?

(AGP): Era. Mas o Nilton Campos sempre me encarregava do primeiro ano e eu acabava dando os três anos de curso. Eu fui aluno do Nilton Campos no curso de Direito e Economia, em 1944. Durante 15 anos, lecionei História da Psicologia. Ao mesmo tempo, já era assistente da faculdade do Estado e na Universidade do Brasil. Na universidade federal, eu comecei em 1948, como professor de Psicologia. Na Universidade do Estado, comecei como interino, em 1950. E fiquei interino até 1970. Fiz duas docências livres e até hoje eu sou o único livre docente com duas docências livres. A uma semana do concurso para efetivação, o reitor recebeu um documento dizendo que eu não poderia ser catedrático. $\mathrm{E}$ suspenderam o concurso. Para acabar com os confrontos, pedi aposentadoria especial; para não ter mais contato com a Universidade do Estado. E fiquei na universidade federal, onde eu já tinha feito o concurso, felizmente. Há muitos anos não havia concurso na Faculdade Nacional de Filosofia mas, em 1965, por uma exigência do Castelo Branco, abriram o concurso. E eu fui o primeiro a fazer inscrição. Quando o diretor perguntou se eu queria concorrer, eu disse: "amanhã"; estava louco para fazer o concurso. Mas tive que esperar três meses. Não tive problemas, fui aprovado. Mas minha carreira foi muito dificultada, porque eu nunca consegui ser diretor do Instituto de Psicologia. Sempre que meu nome ia em primeiro lugar nas listas, era vetado. Até que afinal, em 1979, eu consegui que meu nome fosse aprovado, para surpresa minha, pois já poderia estar aposentado. $\mathrm{Na}$ quela época, começava a haver uma certa abertura e eu pude ser chefe de departa- 
mento de Psicologia na faculdade. O curso foi fundado na Faculdade Nacional de Filosofia e fui chefe de departamento de 64 até 67 , quando a faculdade se extinguiu. Já no Instituto de Psicologia, do qual deveria ser o diretor, mas não consegui por razões políticas, só mesmo em 79. Em 1949, eu publiquei uma monografia sobre Behaviorismo, em homenagem ao Nilton Campos, que havia feito o concurso em 1948. Depois, eu criei, no Instituto de Psicologia, o Boletim do Instituto no qual escrevi muitos artigos. O Instituto de Psicologia foi o herdeiro do Laboratório de Psicologia da Colônia de Engenho de Dentro. Na verdade, ele foi criado por volta de 1932. Em 1937, ele já fazia parte do Ministério da Saúde; só em 1939 é que ele foi incorporado à Universidade do Brasil.

\section{(EP): Quem trabalhava na Colônia, na época?}

(AGP): O Nilton Campos, que era psiquiatra, foi discípulo do Waclav Radecki. Logo que terminou o curso, ele foi para o Engenho de
Dentro, a Colônia dos Psicopatas, como o Engenho de Dentro era conhecido. $\mathrm{Na}$ época em que ele trabalhou lá, o Engenho era dirigido pelo grande higienista Gustavo Riedel. E foi Gustavo Riedel que pensou em montar um laboratório de pesquisas psicológicas para ajudar aqueles psiquiatras que estivessem interessados em fazer pesquisas sobre os doentes mentais da colônia. Ele pensou em criar esse laboratório e, por sorte, encontrou o Waclav Radecki, que havia sido assistente do Claparède. Radecki era professor na Universidade Livre de Varsóvia e chefe do Laboratório Experimental de Cracóvia. Ele veio para o Brasil como imigrante e foi para o Paraná, onde há uma colônia polonesa muito grande. Ele era grande violoncelista e até chegou a montar um quarteto de cordas no Paraná. Uma vez veio ao Rio, entrou no sebo e viu um livro de Psicologia de um professor do Instituto de Educação. Achou interessantíssimo. Então ele procurou contato com esse professor, que era o Lourenço Filho. E o Lourenço terminou indicando o Waclav Radecki para a 
chefia do laboratório. Ele foi contratado para lecionar e fazer pesquisas. Depois disso, foi à Europa comprar equipamentos de pesquisa e conseguir verbas para a fundação, o que ocorreu em 1925. Era um homem muito habilidoso; fez muitos aparelhos de madeira, servindo à pesquisa. Foi ele, inclusive, quem realizou a primeira grande preparação dos psicólogos que trabalharam na primeira seleção de pilotos de aviação. A primeira aplicação de Psicologia nas Forças Armadas. Daí se iniciou a relação entre o antigo Laboratório e o Instituto de Psicologia, no qual o Laboratório se converteu.

\section{(EP): Como Radecki deu se-} qüência a esse trabalho?

(AGP): Ele deu um curso sobre Psicologia Geral para médicos, militares, com o objetivo de prepará-los para realizar, sob a direção dele, as provas na seleção de aviadores. Era um curso interessantíssimo, com capítulos magistrais. Mas o fato é que se estabeleceu uma ligação entre a Aeronáutica e o Instituto de Psicologia. Em 1953, eles quiseram realmente introdu- zir a cadeira de Psicologia nos cursos de formação do Estado Maior. Eles convidaram o Nilton Campos, que era o assistente principal do Waclav Radecki. O Nilton Campos era muito doente e, na última hora, não pôde lecionar. Foi aí que me chamaram. E, de repente, fui jogado para dar $o$ curso. Acontece que gostaram muito e, de 1953 até 1968, eu dei cursos. Depois disso, durante anos, utilizaram apenas o meu manual de Psicologia Aplicada ao Trabalho. Na verdade, era quase um curso de Psicologia Social, que incluía temas como liderança, disciplina, propaganda e também seleção. Então continuou a relação entre o Instituto de Psicologia e a Aeronáutica.

\section{(EP): E com o Exército, não havia nenhum contato?}

(AGP): Nessa época, ainda não. O contato ocorreu quando eu fui convidado para ser um dos fundadores do CEPE - Centro de Estudos do Pessoal do Exército, onde eu também dei aulas. Mas depois começaram a estória que eu era contra os militares, de que era um subversivo. 
(EP): O senhor teve muitos problemas com os militares?

(AGP): A chamada Revolução quase acabou comigo. Sofri várias punições na universidade porque eu não punia ninguém $\mathrm{O}$ Passarinho mandou abrir um processo com três membros, presidido por um embaixador. Um deles estava querendo que eu fosse punido mesmo, mas os outros dois sempre estavam a meu favor. Por sorte, eu ganhei de dois a um. Na verdade, não encontraram nada que me incriminasse. Achavam que eu era muito liberal à subversão no Instituto de Psicologia.

(EP): Exigiam que o senhor punisse os estudantes?

(AGP): É. Na época, eu coordenava o curso de Psicologia e não poderia punir alguém que pedia melhores aulas, porque eu concordava com os alunos. Quem pode punir um aluno que se recusa a assistir aulas de baixa qualidade? Quem pode punir um aluno que está apenas solicitando o que é uma obrigação da universidade? Então, eu sempre pedia tempo para dar uma solução política; para não desmoralizar o professor. Eu sabia que se tivesse qualquer outra atitude, a punição era certa em cima deles. $\mathrm{Na}$ verdade, quem mandava era o agente de segurança. Mas, felizmente, depois de muitos meses, até curso de Fenomenologia ele fez. Fui acusado de ser fenomenologista, porque a Fenomenologia era considerada um disfarce do marxismo. O gestaltismo também era considerado um disfarce do marxismo. Então o agente tomou aulas para saber o que era isso. Bem, depois que terminou o inquérito, não ficou provada nem uma palavra contra mim. Mas, de qualquer modo, eu atravessei uma fase difícil, apesar de ter sido durante 17 anos professor da Escola da Aeronáutica, onde introduzi um curso de Psicologia Social, de 1953 até 1970 . Fui até condecorado pelo presidente Castelo, em 1964. Depois começaram rumores de que eu assinara protestos contra as violências cometidas pelos policiais militares, pelas Forças Armadas. Isso quando invadiram o Campus da Praia Vermelha, espancaram e prenderam estudantes. Eu, de 
fato, assinei e depois presidi duas reuniões de protesto. Naquela época, quem protestasse ou quem não rezasse pela cartilha deles, era punido. Apesar disso, tive meu livro - Manual de Psicologia Aplicada adotado, adotado até 1970. Depois disso, nunca mais fui convidado para nada. Nem para entrar na escola. Apesar de ter grandes amigos militares, de nada adiantava. Em 1964, como eu disse, fundei o curso de Psicologia na universidade. Em 64 já estava funcionando o curso na Faculdade Nacional de Filosofia, não no Instituto de Psicologia. O Instituto de Psicologia era um órgão complementar, de apoio às cadeiras de Psicologia Geral e Psicologia Educacional, dadas nos cursos de Filosofia e de Pedagogia, respectivamente. A cadeira de Psicologia Geral era dada pelo Nilton Campos e a cadeira de Psicologia Educacional pelo Lourenço Filho.

(EP): Foi nessa época que o senhor esteve no Rio Grande do Norte?

(AGP): Foi. Em 1963, eu era assistente do Nilton Campos.
Neste ano, o Nilton, que já estava muito doente, faleceu, e eu assumi interinamente a cátedra. Um dia, fui procurado por um aluno do Rio Grande do Norte, o presidente do diretório dos estudantes. Não me lembro do nome dele, só lembro que depois ele se tornou deputado federal.

(EP): João Faustino. Hoje é suplente de deputado federal e já foi secretário de Educação e diretor da Escola Técnica Federal.

(AGP): Pois é, ele me convidou para fazer umas conferências lá em Natal. Em 15 dias recebi passagem e, eu que nunca tinha voado, fiquei terrivelmente amedrontado com a viagem. Naquela época era muito tempo de vôo, lembro até que o avião era da Panair. Cheguei em Natal de noite e foi uma surpresa , não tinha nenhum hotel, em 1963. Foi a primeira viagem que eu fiz para dar um curso. Eu já havia viajado para aprovar cursos de Psicologia, pelo Conselho Federal, mas esta foi a única vez que recebi um convite de um diretório acadêmico. Fiquei encantado com Natal, com a atividade 
intensa no plano da Educação, as escolas "De-pé-nochão-também-se-aprende-aler", do Djalma Maranhão e do Paulo Freire. Lembro da enorme quantidade de professores de São Paulo que estavam visitando o interior do Estado. Eu fiquei encantado com Djalma Maranhão, o trabalho que ele estava fazendo; depois eu soube que ele foi violentamente varrido pela Revolução. Fiquei encantado com o que assisti naquele momento, com as aulas à noite, as barracas de palha, todo mundo tendo aula, uma dedicação. Eu achei que o Rio Grande do Norte era todo uma lição de como se deveria fazer Educação. E pensei, se isso estivesse acontecendo em todo o país, como seria muito importante para o Brasil.

(EP): O senhor tem muitas publicações. $O$ senhor utiliza um método para sistematizar os conteúdos?

(AGP): Desde cedo comecei a publicar. Primeiro publiquei Psicologia da Percepção e Aprendizagem. Percepção e Realidade, foi o segundo livro. $\mathrm{Na}$ verdade, foram frutos dos cursos que eu fui dan- do na Psicologia. Eu tenho o hábito de fazer roteiros de aula, dava os cursos com eles; depois, transformar em livro era fácil. Comunicação e Linguagem foi o primeiro curso de Psicolingüística dado no Brasil, em 1966. E o livro saiu em 70, com o prefácio do professor Lourenço Filho. Depois eu publiquei 53 verbetes na Enciclopédia Mirador Internacional, com mais de 500 laudas. Publiquei ainda Linguagem, Personalidade e Terapia e Introdução à História da Psicologia Contemporânea. Este último teve um impacto muito grande. Certa ocasião, encontrei em Ribeirão Preto, José Aparecido, que hoje é um grande pesquisador em Psicologia da Percepção, especialmente em Psicofísica. Ele me mostrou um recorte que havia retirado de uma revista americana com um vasto elogio à minha História da Psicologia. Curioso é que foi feito por um peruano que estudava na Alemanha, com o maior historiador da Psicologia da Alemanha. Ele até ficou surpreso porque, conforme registrou, era o primeiro livro de História da Psicologia com um capítulo sobre Fenomenologia. 
Estava estarrecido porque imaginava que só na Alemanha dessem importância à Fenomenologia. Por causa disso, recebi uma carta de um grande historiador americano, pedindo que eu remetesse um exemplar. Ele ficou entusiasmado e me convidou para participar de um congresso que estava preparando para ser realizado em 1967, na Alemanha. Lá, havia um instituto para o estudo da moderna História da Psicologia, com um grande simpósio em homenagem a Fechner, porque exatamente se deu na época do centenário da morte dele. Ele queria que eu fizesse uma apresentação, mas eu estudei muito Fechner, nos cursos de Psicologia e Filosofia, e nas aulas de Psicologia, em função das críticas que foram feitas por Bergson. Então, ele sugeriu que eu escrevesse sobre isso. Eu acatei; elaborei um trabalho sobre Bergson e as suas críticas a Fechner. Foi uma surpresa, descobri que entre os presentes, ninguém conhecia Bergson. Descobri também que, em geral, os alemães não estão muito atualizados com o que se faz na França. Eles dão muito mais importância ao que se produz na Inglater- ra ou na Itália. Depois, recebi muita correspondência me perguntando sobre as obras de Bergson. Escrevi ainda Introdução da Psicologia Contemporânea, Motivação e Aprendizagem e História das Idéias Psicológicas. Esse último foi um livro a pedido do Zahar. Ele havia publicado um outro livro (A História da Psicologia) e, posteriormente, descobriu que os autores haviam copiado o livro de Max Wertheimer. Ele ficou muito chateado e foi obrigado a retirar o livro de circulação. Então, me pediram que eu escrevesse. E eu escrevi rapidamente, estava com tudo na cabeça, era ir para a máquina e bater. Na verdade, era exatamente o curso que eu, durante 15 anos, dei na Faculdade Nacional de Filosofia, apenas com uma introdução da História da Ciência, que em geral pouca gente estuda. Um pouco de história da ciência é absolutamente necessário. Depois, escrevi sobre 4 ou 5 processos cognitivos, um resumo sobre Percepção, Linguagem, Motivação e Atenção, e fiz um estudo sobre introdução à Psicologia Cognitiva, em 1984. Em 1987, publiquei Cognitivis- 
mo, Consciência e Comportamento Político. Em 1988, História e Psicologia. Neste livro, faço referência à importância do tempo em Psicologia, o longo tempo e o tempo breve em Psicologia. Falo também de diferentes temas. Não sei se é nesse livro que tenho um trabalho sobre Psicologia Existencial, as bases do pensamento existencial, fundamentalmente baseado nas idéias de Jean Wahl, o grande nome na divulgação do pensamento existencial na França, o grande historiador da Psicologia Existencial. Em 1990, publiquei Filosofia da Mente; em 1992, História da Psicologia no Rio de Janeiro. Depois escrevi Freud, as Ciências Humanas e a Filosofia. E, ultimamente, Introdução à Psicologia Política. Ao todo, são 14 livros publicados, além da monografia sobre Behaviorismo e do manual de Psicologia aplicada às Forças Armadas. E, no momento, eu estou preparando dois livros: Psicologia da Religião e Filosofia Moral. Isso porque recentemente fui convidado para a aula inaugural na Escola da Magistratura do Rio de Janeiro. Eu já havia sido convidado em
1992 para uma jornada sobre Ética para Juízes. Queriam que abrisse a jornada e eu fiz a conferência inicial. Falei sobre o conceito de Ética, mostrando a impressão que eu tinha de que, no exercício da magistratura, o indivíduo que tem em suas mãos o destino de um outro, em termos de condená-lo ou absolvê-lo, deve viver um estado de angústia muito grande. E quem não vive esta angústia, não tem condições de ser juiz. A vivência, a experiência da angústia, tem de ser uma condição fundamental para todo aquele que tem nas mãos o destino de um ser humano. Nesta conferência, estava presente um professor de São Paulo, o diretor da escola de magistratura paulista, e ele pediu para editar um livro, que saiu em São Paulo pela Revista dos Tribunais, com o título de Ética através dos tempos.

(EP): Fale-nos um pouco sobre seu interesse em Filosofia da Religião?

(AGP): Meu interesse por essa área é antigo. Fui discípulo do homem que, a meu ver, foi a maior cabeça filo- 
sófica que nós tivemos: padre Penido. Muita gente pensa que falar sobre Filosofia da Religião é fazer apologia da religião. Não é. Recentemente, fui à Inglaterra e li um livro sobre Filosofia da Religião, de um professor americano. Esse livro me causou um impacto muito grande. Um livro absolutamente cético. É uma crítica no sentido kantiano, uma crítica aos fundamentos da religiosidade, da experiência religiosa, do misticismo.

(EP): O senhor estudou com o padre Penido?

(AGP): Ele foi meu professor de Filosofia. Ele era brasileiro, mas quando estava estudando em Friburgo, na Suíça, foi contratado pela Escola Nacional de Filosofia do Rio para ensinar Filosofia e acabou ensinando Psicologia Religiosa. Penido lembrava muito o papa Pio XXII: magro, seco, quase não sorria, muito fechado. Um professor fantástico e brilhantíssimo. E ele era encantado por Bergson, que foi o filósofo que eu mais estudei na faculdade. Em 1932, Bergson escreveu um belíssimo livro sobre religião e moral: Les deux sources de la morale et de la réligion. Nesse livro, ele fecha praticamente sua obra. Ele foi muito coerente, e grande parte desta obra foi dedicada não à moral, mas à religião. Inclusive, um belo capítulo sobre misticismo. Ele tinha um grande entusiasmo pela experiência mística.

\section{(EP): O Professor Penido aceitava o misticismo?}

(AGP): O Penido criticava muito os críticos do misticismo, inclusive Pierre Janet, que considerava os místicos psicastênicos. E dele ouvi o argumento que mais me impressionou: quando um atleta se dispõe a marcar um recorde olímpico, almeja a medalha de ouro, é submetido a um treinamento exaustivo, tem um objetivo, uma motivação para o seu desempenho. Isso é dignificante, o ser humano a descobrir os seus limites. Mas se alguém faz tudo isso com o objetivo de se aperfeiçoar moralmente, deve ser um doente mental. Essa era a tese do Pierre Janet. Eu sempre me interessei por esse tema por causa do 
Penido. O Penido escreveu uma obra maravilhosa, em francês: La conscience religieuse. Considero a mais brilhante da Psicologia na área da religião, embora nunca tenha sido traduzida para o português. Ele deu um curso maravilhoso na Suíça, inclusive, eu tenho me aproveitado muito quando falo nesse assunto.

\section{(EP): Em síntese, o que foi} esse curso?

(AGP): Penido divide o estudo da experiência religiosa em três grandes etapas: desde o momento em que o indivíduo se converte, passando pelo momento em que é submetido a uma série de práticas ascéticas para aperfeiçoar-se moralmente e, finalmente, o momento em que chega ao misticismo, que é a experiência religiosa sem igreja. Há um trabalho do maior pensador polonês vivo - hoje com 70 anos, chamado Kolakowski. Ele foi o maior expositor do marxismo. Ele foi membro do partido comunista na Polônia mas rompeu com o partido, foi expulso e teve de sair da Polônia. Então, foi para a Inglaterra, tor- nou-se professor na Universidade de Oxford. Também lecionou na Universidade de Yale, em Chicago. Ele tem uma variedade imensa de obras. Uma delas sobre Filosofia da Religião, dividida em três capítulos: o Deus da Odisséia de Leibniz, o Deus dos Racionalistas de Descartes e o Deus dos Místicos. Neste livro, com 800 páginas, ele estuda estas três concepções de Deus. Ele fala sobre os místicos do século XVIII, que estão convencidos da possibilidade de contato direto com Deus; dispensam a igreja, a hierarquia eclesiástica, convivem com Deus, sem necessidade dos padres, bispos. Por isso, são cristãos sem igreja. Eles eram muito frequientes no século XVII, quando houve a grande Reforma de Calvino e Lutero. Eu me lembro da análise feita, quando li a peça de Bernard Shaw sobre Santa Joana d'Arc, mostrando que ela não foi queimada viva por motivos religiosos, mas motivos políticos. No momento em que ela dispensava a Igreja, estava ameaçando a Igreja, e ao antecipar-se à Reforma se antecipava também aos místicos, que pretendiam ser 
cristãos sim, mas sem igreja. Mas, ao mesmo tempo, esse contato direto com Deus, com o poder máximo, implicava uma crítica terrível ao Feudalismo. Então, as razões políticas fizeram com que ela fosse queimada viva.

(EP): Então seu tema atual é Filosofia e Religião?

(AGP): É, mas obviamente não é só isso. Tenho grande interesse também em História da Filosofia, Ética e Política. Inclusive, recentemente, proferi conferência sobre a História da Filosofia no Rio de Janeiro.

$(E P): O$ senhor tem também um interesse pela Fenomenologia.

(AGP): Eu tenho uma grande base em Fenomenologia. Enquanto aluno na faculdade, trabalhei muito, dei aulas. Fui um bom especialista em Merleau-Ponty, que é uma das figuras mais importantes da Fenomenologia. Ele vinculou a Fenomenologia à Filosofia Existencial, embora sejam coisas que a gente tenha de separar sempre.
(EP): Então o senhor questiona essas terminologias, Psicologia Fenomenológica Existencial, Psicologia $\mathrm{Hu}$ manista Existencial?

(AGP): Apesar de se falar muito freqüentemente em Psicologia Fenomenológica e Existencial, eu sempre fui contra isso. Uma coisa é a Psicologia, a Fenomenologia e o método fenomenológico e outra coisa é a Filosofia Existencial. Tem-se de fazer logo uma distinção que é fundamental: de um lado a Filosofia Existencial e, de outro, o Existencialismo. A diferença está em que, quando se fala em Existencialismo, se está pensando em uma corrente que trabalhou praticamente com a natureza humana; é uma antropologia. Por exemplo o existencialismo de Sartre, Jaspers, Marcel, que são centrados no estudo do Homem, na existência humana, no problema da liberdade, da escolha, etc. A Filosofia Existencial é fundamentalmente Heiddeger e aqueles que o seguiram. O que caracteriza a Filosofia Existencial é o fato de que ela se utiliza da experiência humana, mas o objetivo dela não é estudar 
o ser humano; é um objetivo ontológico (estudar o ser), e não antropológico (estudar o homem). Mas, como eu quero alcançar o ser e o único ser que pode dar um depoimento é o ser humano, então se começa pela Antropologia. Mas o objetivo não é o ser humano. O objetivo é discutir o problema do ser, da natureza do ser e dos entes. Por outro lado, uma terceira característica importante é que a Filosofia Existencial nunca usou o método fenomenológico como Husserl o concebeu, e nem poderia usá-lo exatamente.

\section{(EP): Por que?}

(AGP): Porque o que caracteriza o método fenomenológico em Husserl é o descartamento total dos aspectos existenciais para se concentrar nos aspectos essenciais, na essência. Ele está interessado na essência do ser. Isso faz com que, quando se fala em método fenomenológico, se pense principalmente no método tal como Husserl o empregou, com aquelas reduções contínuas. Agora, no caso de Heiddeger, quando ele fala em método fenome- nológico, o método dele foi progressivamente se afastando, e depois, não tinha mais nada a ver com o de Husserl. E ele, inclusive, critica muito aquela preocupação excessiva, que deixava os alunos entediados de tanto que Husserl falava em redução.

\section{(EP): Então são duas cor- rentes?}

(AGP): Sim. Há a Psicologia Existencial e a Psicologia Fenomenológica. Nos cursos de Merleau-Ponty, a gente vê que o trabalho foi muito com o conceito de existência mesmo, até no sentido da tradição de Kierkegaard. O primeiro nome é mesmo Kierkegaard e nós temos mesmo que estudá-lo porque há pelo menos 16 teses fundamentais para caracterizar a sua contribuição. Uma delas é que enquanto em todos os animais a espécie é mais importante que o indivíduo, na espécie humana, o indivíduo é mais importante que a espécie. É a exaltação do indivíduo, e essa exaltação é realmente que cada um de nós é único, não tem outro igual. E a nossa individualidade é tão importante que, como diz 
um grande nefrologista francês, você transplanta um rim e o rim é rejeitado; é como se você dissesse: "ou a minha individualidade é preservada ou eu prefiro a morte". Isso é muito bonito, porque o sujeito rejeita, e só podemos impedir a rejeição, se enfraquecemos o sistema de defesa do indivíduo, o sistema imunológico. Aí o sujeito aceita qualquer coisa, mas perde a individualidade.

(EP): No seu texto "Repensando a Psicologia", o senhor coloca a Psicanálise no âmbito da Psicologia, contrariando as idéias de muitos psicanalistas.

(AGP): Neste trabalho, eu falo da necessidade de acabar com esta estória de que a Psicanálise não tem nada a ver com a Psicologia. É preciso salientar que a Psicologia não tem unidade. $\mathrm{O}$ que caracteriza a Psicologia é o fato dela mobilizar muitas metodologias: quando se fala em Psicanálise, mobiliza-se uma metodologia hermenêutica, quando se fala em Psicologia Experimental, mobiliza-se uma metodologia positiva; uma metodologia fenomeno- lógica, quando se fala em gestaltismo, uma concepção realmente fenomenológica, não existencial. Então acho uma estupidez separar a Psicanálise da Psicologia. O que eu discuto é a impossibilidade de unificação da Psicologia.

\section{(EP): E quanto as críticas ao gestaltismo?}

(AGP): A preocupação dos gestaltistas foi sempre em detectar a essência da percepção. Eles fizeram as práticas da redução; eles procederam exemplarmente porque quando Wertheimer estudou a percepção, não estava preocupado com as influências emocionais, influências derivadas da personalidade, nada disso. Eles deixaram tudo isso de lado. E a crítica de que eles fizeram uma Psicologia sem sujeito, feita pela New Look in Perception, por Postman e por todos que integraram esse movimento, foram injustas. Portanto, não é verdade que eles fizeram uma Psicologia sem sujeito. Eles deram muita importância ao fator "setting", ao fator atitude do sujeito. Agora, o que eles deixaram de lado foi o seguinte: 
não interessa estudar a influência dos fatores emocionais - sem dúvida eles existem mas essa influência não é substantiva; ela é puramente adjetiva. Se eu quero saber o que é a percepção; a mim interessa pegar a percepção no estado de pureza total e, nesse estado, posso deixar de lado as influências emocionais, influências históricas, etc.

(EP): O senhor se referiu à falta de unidade na Psicologia? Essa é uma característica transitória na Psicologia?

(AGP): Eu não vejo saída, continuo achando que nós temos de conviver com uma diversidade de enfoques muito grande, até porque o ser humano é um ser que foi muito bem visto por Augusto Comte. Comte tem uma observação extremamente importante, que pouca gente fala. Quando ele escreveu o Curso de Filosofia Positiva, por volta de 1836 , dizia que a Psicologia científica, a Psicologia positiva, na verdade não existe: passa-se da Biologia para a Sociologia. Aparentemente ele negava a cientificidade da Psicologia, mas ele dizia que talvez a Psicologia pudesse ser fundada com base nas idéias da Galton: a Frenologia. Não que ele acreditasse na Frenologia, mas pela primeira vez, alguém dizia coisas que podiam ser submetidas a verificação e rejeitadas. A cientificidade estaria exatamente nisso: a possibilidade de verificação. Em 1851, ele faz uma série de afirmações sobre a Psicologia. Diz que Psicologia científica ainda não está fundada; no dia que for fundada, ela terá de ser, e não poderá deixar de ser, senão fundada na Biologia e inspirada na Sociologia, quer dizer, no estudo do ser humano. Você pode dar uma ênfase muito grande em abordagens neurocientíficas, abordagens biológicas, mas não pode esquecer que tudo quanto você faz, tudo quanto vê, pensa, está sob a influência da cultura, da linguagem. Da linguagem exprimindo a cultura, sendo ao mesmo tempo um obstáculo, porque a cultura ao cunhar a linguagem, cunha de tal maneira, que você vê apenas aquilo para o qual a cultura tem palavras. Então, desde aí, você tem 
uma divisão da Psicologia. A História da Psicologia não foi outra: de um lado a Psicologia Social, e de outro, a Psicologia Biológica. Quando se fala de uma Psicologia Biológica, pensa-se numa Psicologia totalmente dominada pela metodologia das ciências físicas naturais. Mas aí também cabe uma outra divisão: você pode descobrir que o corpo não é um corpo qualquer, ele está dominado pela mente, que é um produto emergencial. Surge emergentemente a partir do momento que ela emergentemente surge e passa a dominar o corpo. Então, não posso estudar o corpo como um objeto qualquer, tenho de estudar o corpo próprio, tal como eu experimento, e eu experimento não como uma coisa, mas como algo que é totalmente diferente do resto. Então, já há uma divisão e a divisão permanece. Quando os neurocientistas se debruçam procurando as bases da memória no cérebro, estão fazendo algo que é científico, mas quando se estuda a memória do ponto de vista social, também é ciência pura, mas a metodologia é outra. Então, pensar na unidade da
Psicologia é, a meu ver, difícil de conseguir, embora tenha sido sonho dos positivistas.

$(E P):$ E, dentro desta dispersão toda do conhecimento, do saber psicológico, como o senhor vê o aparecimento dessas abordagens corporais, místicas?

(AGP): Essa é outra coisa que é importante, eu tenho um trabalho, chama-se Automatismo e Subjetividade; eu escrevi inspirado em Pascal. Pascal tem dois pensamentos extraordinários: ele mostra que eu posso alterar a mente através do corpo e posso alterar o corpo através da mente. Ele é dualista cartesiano, mostra que posso desenvolver em você humildade, modéstia, através da exigência de que você assuma determinadas posturas. Por exemplo, quando você se ajoelha, quando olha de baixo para cima, você está de certo modo sendo levada a sentir-se inferior a quem você olha. E o ato de ajoelhar é sentir humildade. Eu posso desenvolver, através de determinadas práticas físicas, uma série de mudanças psicológicas. Mas, ao mesmo 
tempo, posso, através de mudanças psicológicas, determinar efeitos totalmente diversos no campo físico. Foi o que fez Freud, quando trabalhava com a histeria. Ele mostrava que $o$ ato de falar determinava alterações internas, ele se libertava. Catarticamente. É um tema tipicamente pascalino, que mostra como nós encontramos em Pascal uma abordagem interessante sobre as relações do corpo com a mente.

\section{$(E P):$ E quanto às chamadas terapias alternativas?}

(AGP): Recentemente fui convidado para falar sobre esse tema, pela PUC. Eles têm um centro de Teologia, uma associação de psicólogos cristãos e um centro de Fé e Ciências. Pediram que eu fosse mais cedo para ser apresentado aos psicólogos cristãos, e lá eu encontrei realmente muitos terapeutas. Eram associados a esse grupo de cristãos. Encontrei alguns que praticavam a terapia das vidas passadas, apesar de ser um centro católico. Outros praticavam a terapia pela oração. Um crente, que está orando para Deus com fé, pode, pela auto-sugestão, ter benefícios terapêuticos. Descobri ainda que havia uma linha na terapia de vidas passadas que diferia da outra, a que acredita realmente que o indivíduo está reencarnado. Havia lá uma mineira que inventou uma coisa, que me pareceu mais inteligente. Uma terapia das vidas passadas, como se a vida não tivesse sido vivida, a vida que o indivíduo gostaria de ter vivido. É mais projetiva, traduz mais ou menos as características de personalidade. Achei mais interessante. Mas o que me irrita muito na terapia das vidas passadas é que o sujeito sempre foi uma personagem importante do reino de Luís XVI, Luís XIV, e eu não vejo ninguém sendo um miserável, um sapateiro, ninguém tendo uma função humilde. Parece que o pobre já morreu mesmo, não tem nem mesmo direito a reencarnação, só quem reencarna são os ricos. Isso me irrita, pois é o contrário de tudo quanto eu sei de História da Psicologia, e de Psicologia histórica, o que eu aprendi em Psicologia histórica, que não tem nada a ver com História da Psicologia. 
(EP): O que é a Psicologia histórica?

(AGP): É uma corrente no campo da Psicologia, que estuda como os processos mentais se alteram com o tempo. Os gregos não inventaram a razão, mas o tipo de razão, e realmente, a função do tempo altera não só o corpo, mas a mente, e os processos também se alteram com o tempo. Mas, voltando à sua outra pergunta, o que me impressiona é que as chamadas terapias das vidas passadas ignoram a Nova História: a História colocada não do ponto de vista dos reis, das classes mais poderosas e dos grandes generais, mas a história do povo. Na História tradicional, o povo não era lembrado, e estas terapias repetem isso.

(EP): E quanto às abordagens esotéricas?

(AGP): Eu acho essa preocupação em buscar o Oriente, que é uma fuga de nossa cultura para outra, é sempre expressiva de um certo desajuste. Quem leu As duas fontes da moral, de Bergson, sabe que os místicos hindus não atingiram um grande ní- vel; os poucos místicos que alcançaram um maior nível foram posteriores a Cristo, já foram, de certo modo, influenciados pela tradição cristã. Por outro lado, na Grécia houve misticismo. $\mathrm{O}$ ofismo foi um produto do culto de Deus, de Dionísio. O ofismo transformou-se em pitagorismo. Os gregos, pela racionalidade, superaram a tradição mística e converteram-se numa tradição realmente racional. $\mathrm{E}$ com isso não tiveram misticismo. Os grandes místicos foram os cristãos porque, apesar dos judeus terem um sistema místico, com grandes profetas, foram muito marcados pelo nacionalismo. Os judeus nunca fizeram proselitismo, os cristãos é que fizeram proselitismo. Os cristãos desejam que o cristianismo seja cada vez mais numeroso, que venha mais gente para a cristandade, mas os judeus se fecharam, é uma religião nacional. Então, o cristianismo, sendo uma religião universal, teve um nível de alcance maior. Isso dito pelo próprio Bergson, que era judeu. Na época da perseguição nazista, Bergson estava com febre de 40 graus, com pneumonia, 
quando soube que todos os judeus estavam sendo conclamados a se inscreverem num registro de judeus, para serem possivelmente perseguidos. Ele se levantou da cama e, em pleno inverno, colocou-se para ser registrado como judeu, embora já tivesse se convertido ao catolicismo. Isso mostra que, naquele momento de dificuldade, ficar ao lado da antiga ligação religiosa que ele mantivera era o mais importante. Mostra o vínculo com sua cultura. Então, buscar no Oriente uma orientação melhor a que nós temos no Ocidente, acho que é uma fuga da cultura, um desajuste. Não vejo nada de melhor que se possa ter do lado de lá. Há até um trabalho de Max Weber, que é fantástico. O Weber é contra o historicismo, que é a doutrina da história que é regida por leis. Por ela, poderíamos prever o rumo da história. Ele era contra e nos mostra que realmente a previsão histórica é impossível, porque o que prevalece na história são os fatos banais; os dados contigentes, que têm efeitos incríveis, que alteram qualquer predição. Ele chama atenção para o fato de que a nossa cultura é eminentemente grega por um fato extremamente banal. Nossa cultura teria sido, com todos os motivos mais relevantes, uma cultura religiosa, do tipo persa. Mas não foi porque houve uma batalha banalíssima, pequeníssima, insignificante, uma batalha de maratona, no desfiladeiro das Termópilas, quando 300 gregos derrotam o exército persa. E derrotando o exército persa, eles impediram que os persas fizessem na Grécia o que fizeram em todas as colônias que eles conseguiram dominar no Oriente. Ou seja, eles estabeleciam ligações com a religião dominante e impunham a religiosidade, o que permitia a eles o domínio mais fácil. Na Grécia, quem venceu foi a razão, e a cultura que nós herdamos foi a grega.

(EP): Freqüentemente fazse uma ligação entre as idéias de Freud e Marx. Qual é a origem desta associação?

(AGP): Realmente é muito freqüente esta ligação entre Freud e Marx. Porque Marx foi o primeiro a fazer uma crítica a Descartes, na medi- 
da em que Descartes considerava que o mundo pode não existir, mas eu existo. Se eu duvido, eu penso. Eu posso duvidar do mundo, o mundo pode ser um sonho, uma alucinação. Ainda que seja um sonho ou uma alucinação, existe aquele que sonha e vive a alucinação, que sou eu. Então, a minha consciência é alguma coisa que constitui um ponto de partida. E Marx dizia que existe uma falsa consciência; mostrou que a consciência pode fraudar, errar. Ele trabalhou muito com o conceito de falsa consciência no sentido de que eu, por exemplo, não sei quais os motivos pelos quais possa agir desta ou daquela forma. O operariado usava motivos que não eram dele, motivos que eram exatamente da classe dominante. Aí está um exemplo de falsa consciência, de uma ideologia pejorativa, negativa, aquela que faz com que eu sustente como vantajoso para mim, um determinado motivo que me leva a agir, e que, na verdade, é o motivo que só interessa àqueles que dominam a situação social. Então, Marx foi um dos que trabalhou muito com isso. Recentemente escrevi um artigo sobre Lenin e Freud, no qual discuto um trabalho que Lenin escreveu em 1902: O que fazer". Lenin sustentava a tese de que o operariado perdeu a força revolucionária porque um operariado que vive no sistema marcado epistemologicamente por certas categorias impostas pela classe dominante não pode senão pedir aumentos de salário. Então um PT só poderia, segundo Lenin, aspirar e reivindicar aumento de salário, nunca poderia pensar na eliminação do sistema assalariado. Para isso seria necessário alguém que pudesse pensar sem as categorias que dominam o sistema; só alguém de fora. Ele introduz a idéia de que somente alguém de fora, que não seja contaminado pelas categorias lógicas e epistemológicas do sistema, é capaz de jogar abaixo este sistema. Ele imaginou que isso fosse trabalho para o Partido Comunista, arregimentando intelectuais desvinculados do sistema e que poderiam ter liberdade para pensar outras categorias. E foi isso que inspirou Marcuse, quando ele imaginou que o operariado tinha perdido força revolucionária, 
embora com uma ascensão muito grande no primeiro mundo, mas ele tinha de jogar muito com a possibilidade de que a sociedade poderia ser modificada pelos hippies, no final dos anos 60 . Exemplo disso é o filme "Um estranho no ninho", um filme tipicamente marcusiano, embora pouca gente tenha percebido isso. $\mathrm{O}$ momento que marcou é quando o Jack Nicholson tenta levantar, não sei se é um cofre, para jogar contra os grades e se libertar, mas não consegue. Quem consegue é um índio, alguém de fora do sistema. De outra cultura, não contaminado pelas categorias ideológicas dominantes. Isso é tipicamente marcusiano.

(EP): No seu texto "Acerca do corpo máquina e do corpo próprio", o senhor discute o outro lado do dualismo cartesiano. A consciência, a mente pode fraudar. $E$ o corpo?

(AGP): O conceito de corpo é muito importante. Os psicanalistas só falam em corpo erógeno, o aspecto sexual. Nesse trabalho, eu falo de um corpo como sendo não meu; eu não tenho um corpo, eu sou um corpo. Há uma diferença muito grande aí. A minha experiência é de eu sou um corpo. As dificuldades da linguagem, os limites da linguagem, fazem com que eu me refira a mim mesmo como tendo um corpo. Essa é uma influência da tradição dualista. O meu corpo e a minha mente. Então eu sou platônico, todos nós somos platônicos, temos uma dívida aqui e ninguém consegue se libertar dela em relação a Platão. A grande contribuição de Descartes foi apresentar o corpo como uma máquina. $\mathrm{E}$ isso foi de um certo modo aceito até pela medicina do século XIX. A idéia é a de que, assim como se substitui uma peça de um carro, também pode-se substituir uma peça de um corpo humano. Com uma diferença: o automóvel pode se sustentar com qualquer peça, o corpo humano não. O corpo humano repele. Por outro lado, a idéia de máquina está presente por influência do Iluminismo. É a racionalização do trabalho, a idéia de divisão do trabalho em atividades elementares de tal maneira que o indivíduo se automatiza. E isso foi cri- 
ticado genialmente por Chaplin em "Tempos Modernos", quando ele passa o tempo todo repetindo movimentos. Então todo o processo do capitalismo industrial no século XIX se inspirou em Descartes e inspirou-se na racionalização do trabalho, no fundo transformando o trabalhador numa máquina. Corresponde, de um lado, à linha filosófica com Descartes e, de outro lado, a linha social com a racionalização do trabalho, transformando o Homem numa máquina. E, obviamente, quando Marx fez a grande crítica do capitalismo, ele estava tentando libertar o ser humano dessa condição. E, em princípio, todo psicólogo industrial, que faz Psicologia Industrial tem de trabalhar muito com isso. Mas, infelizmente, em geral, os psicólogos que se dedicam à Psicologia do Trabalho ficam inteiramente integrados ao Sistema, porque falta a eles a formação em História Social. Eles não têm nenhuma visão de História Social.

$(E P):$ E por que ocorre isso? É um problema de formação?

(AGP): Eu tenho uma razão muito simples. Vou tomar meu próprio exemplo. A primeira cadeira que eu dei na minha vida, em 1940, no início da minha carreira, foi sobre História Econômica. Hoje estou com 56 anos de sala de aula. Eu me lembro até hoje, dei um curso sobre economia pré política - a economia dos primitivos, em que eu me utilizava muito dos antropólogos, depois eu discutia a economia grega, que não conhecia a propriedade privada, conhecia a propriedade familiar, e com as revoluções, as tentativas de implantar na Grécia a reforma agrária. Depois, eu estudava a economia italiana romana, depois a economia medieval, com o sistema feudal, com o sistema das corporações de ofício, e a origem progressiva do sistema capitalista, através da evolução das cidades, as quais tiveram que ultrapassar as muralhas que as cercavam, e tudo quanto estivesse fora das muralhas, fugia ao controle das corporações e, conseqüentemente, permitia a economia de mercado. Foi aí que começou o capitalismo. E depois do capitalismo, Marx, com o estudo do capitalismo industrial, comercial, financeiro e o imperialismo. Foi um curso que eu dei de 
1940 até 1945 , dava a visão histórica. Então, eu acho que a falta de formação em História Social impede a visão histórica dos psicólogos e os integra ao Sistema.

(EP): Que outras disciplinas seriam importantes na formação do psicólogo do trabalho?

(AGP): Acho o estudo da História do Trabalho imprescindível. O estudo histórico do trabalho é uma coisa lindíssima, porque nós temos duas grandes influências sobre a nossa cultura: a influência judaico-cristã e a influência grega. Infelizmente, prevalece na área cultural, a influência grega. A influência judaica ficou principalmente limitada à área religiosa; a grande influência foi a grega. E o conceito de trabalho que nos foi transmitido pela tradição judaico-cristã é o trabalho como pena, pelo pecado original. O homem pecou, então, vai ganhar a vida com o suor do rosto, a mulher vai parir com dor e a serpente vai rastejar por toda eternidade. É uma idéia de punição terrível que recebemos da tradição judaica, o trabalho como uma maldição, um castigo. Na tradição grega, o trabalho era escravo, mas não era a escravidão que nós conhecemos depois da descoberta da América; era a escravidão dos prisioneiros de guerra, que poderiam ser intelectuais, príncipes e até nobres. Eram presos e transformados em escravos para o trabalho. $\mathrm{Na}$ verdade, em Platão, nas Leis, já há um pequeno texto, comentado até por Marcuse, no qual ele diz que o trabalho pode ser perfeitamente erotizado, o trabalho pode ser algo realizado com grande prazer, com um imenso prazer. É a possibilidade de que o trabalho seja uma coisa muito agradável. E eu pensei que esta pudesse ser uma tese notável de Claparède. Claparède escreveu um texto notável sobre trabalho e jogo, no qual ele mostra que o trabalho nas suas formas superiores identifica-se perfeitamente com o jogo e, só nas formas inferiores, é que ele se divide. O jogo é sempre alegre, e o trabalho, nas formas inferiores, é escravo, é punição. Por exemplo, o jogo de xadrez é terrível, no sentido de levar o sujeito à exaustão e, entretanto, é um jogo ex- 
tremamente agradável. O trabalho é tão agradável que o indivíduo esquece de jantar ou almoçar. Se ele está envolvido no tema que o está encantando, se ele está tendo insights, ele não quer nem ser perturbado.

(EP): É essa sua experiência pessoal com o trabalho?

(AGP): Felizmente, eu tenho essa experiência de trabalho. Eu trabalho muito, escrevo muito, mas escrevo com enorme prazer e fico feliz quando eu termino um artigo. E como se eu tivesse tirado uma loteria. Quando eu tenho idéias que me parecem originais, eu me sinto assim como agraciado com presentes que não têm preço. Mas, para isso, é importante que a gente estude a História do Trabalho, o trabalho na Idade Média, na Idade Moderna, o significado da divisão do trabalho, tudo isso fez com que o homem perdesse a visão do conjunto e se sentisse realmente infeliz, porque não chega a produzir nada que possa ter sentido. Mas, ao mesmo tempo, eu chamo atenção para o fato de que se alguém é um bom marcenei- ro, mas trabalha numa loja, numa fábrica, trabalha 8 horas, e quando vai para casa, vai para o fundo do quintal para fazer os móveis de casa, isso pode ser algo muito prazeroso. É um prazer porque ele é um artista, e um artista não se cansa porque ele está sendo profundamente beneficiado pelo ato de criação. Mas isso não se estuda em Psicologia do Trabalho. Geralmente como é dada é uma cadeira triste, e o tema é realmente lindo. Seria necessário que se estudasse o conceito de trabalho com a visão filosófica e histórica para se compreender a própria atuação do psicólogo. Por exemplo, uma coisa que me irrita é o empresário dizer: eu garanto 5.000 empregos, dou 5.000 empregos, sou importante porque forneço empregos. A formulação está errada, ele não dá, ele precisa de 5.000 trabalhadores para que ele possa realizar o que está querendo. Mas ele inverte e dá a impressão que ele é que está doando, quando na verdade o ato de produção é coletivo, a repartição que é injusta. A injustiça começa no momento em que se divide o apurado, mas o ato de produção é ab- 
solutamente um ato de natureza social; é sempre fundado num processo cooperativo. Está todo mundo trabalhando, inclusive, o próprio dono da empresa também trabalha. No fim, o operário ganha um salário vil, o salário mínimo, e o empresário fica com quase tudo. A questão é que não se olha para o outro com fraternidade, que foi a grande descoberta da Revolução Francesa. A liberdade é incompatível com a igualdade, só deixando de sê-la, pela fraternidade.

(EP): E, de modo geral, como o senhor vê a questão do ensino e da pesquisa em Psicologia na academia, nas universidades?

(AGP): Cada vez mais acho que o ensino está totalmente errado. Quando eu começo um curso, peço aos alunos que não acreditem em nada do que eu vou dizer. Peço apenas que tomem aquilo como um estímulo para o estudo, mas não acreditem em nada, pois se tudo que eu dissesse fosse verdadeiro, não haveria História da Ciência. A História da Ciência é uma história de erros, que se cor- rigem continuamente e, ao mesmo tempo, uma lição de modéstia. Estudar História da Ciência é ser modesto, é perceber que todas as chamadas Verdades, que foram engrandecidas, de repente foram jogadas abaixo. Nós vivemos numa cultura centrada na importância das respostas - e as respostas são decoradas. Às vezes, numa sala de aula, ninguém pensa, o pensamento é a coisa mais rara. Nietzsche tem uma frase maravilhosa: "na Alemanha já não se pensa mais. Repetese". A verdade é que quando digo que não se pensa numa sala de aula, é porque o professor está ensinando um falso problema, porque ele conhece o resultado, então para ele não é um problema. E os alunos não escolheram aquele problema, não o descobriram. Estão ali atendendo a uma solução, aprendendo uma solução; o que é importante é a solução, é aprender a solução. Quando mais importante do que qualquer solução que se aprenda, é a importância da pergunta. Porque a pergunta revela uma motivação epistêmica, revela que, de repente, você viu alguma coisa e se espantou; exige 
uma resposta, uma explicação, uma resposta. Por exemplo, na medida em que a criança faz perguntas e o adulto responde, ela vai diminuindo a frequiência de perguntas. Quando ela se converte num adulto, não faz mais perguntas, ela repete respostas dadas pelo professor em sala de aula. O professor, por sua vez, ouviu do seu professor aquelas respostas. Ele repete aquilo, a segunda geração repete novamente, a terceira geração repete e realmente o ato de perguntar é raro. Eu costumo dizer que o bom professor é aquele que, quando sai da sala de aula, sai sabendo mais, ele não se limitou a repetir. É preciso que a aula seja um momento para pensar e o professor pense também que esteja ali, humildemente, para aprender um pouco mais. Às vezes, o aluno faz uma pergunta e o professor não dá atenção, e aquela pergunta era realmente importante. É preciso valorizar a pergunta. $\mathrm{Na}$ área da pós-graduação, estamos dominados pela compulsão à repetição. E isso é uma prática mundial. Quan- do você entra no mestrado, a primeira providência é encontrar um professor para a orientação. O professor diz, então, que só orienta se for na área dele, e a área dele é a área do professor que o orientou. $\mathrm{O}$ professor que o orientou trabalha nessa área também porque foi orientado por alguém dessa área. O que ocorre é que todo mundo está repetindo, trabalhando com pequenas variáveis, mas no mesmo problema. O importante no mestrado é o aluno ter coragem de dizer: "eu gostaria de estudar isto, isto é que me interessa", e o professor dizer: "eu não sei, mas vamos estudar juntos". Ele tem muito mais estudo, muito mais disponibilidade de leitura que o aluno, então, ele pode ajudar, mesmo que nunca tenha feito um trabalho naquela área. Ele vai estudar junto com o aluno e ambos vão aprender e progredir.

\section{(EP): Muito obrigado por sua entrevista.}

(AGP): Eu é que agradeço. 